\title{
13
}

\section{Theorizing Māori Women's Lives:}

\section{Paradoxes of the Colonial Male Gaze}

\section{Patricia Grimshaw and Helen Morton}

Joel Polack was an adventurer who arrived in New Zealand in 1831 and, like so many of his fellows, set out to make a good living wheeling and dealing in goods and land with Māori people, first in Hokianga and subsequently in Kororareka. He became more notable than most early settlers, however, by writing of his experiences. His New Zealand: Being a Narrative of Travels and Adventures ... 1831-1837 appeared in 1838, followed by the two-volume Manners and Customs of the New Zealanders in 1840, the year in which the British claimed sovereignty over Māori and their lands. Polack gained a reputation as a land shark, a charge that he vehemently denied in the preface to his Manners and Customs. In 1838 he traveled to London to give evidence to a Select Committee of the House of Lords in support of the colonization of New Zealand, whence he returned for a period when the British took possession.

As was usual in early accounts of New Zealand travels, Polack attempted to describe Māori society for his English readers, and in doing so specifically addressed Māori women's life experience. His anecdotes and descriptions of Māori life, mundane or extraordinary, abound with details of Māori women as individuals. He told of women's active participation in all of the tribal groups' affairs, of their energy, their outspokenness, and their efficiency: "In New Zealand they eat with the men, accompany their lovers, husbands, relatives, and friends, to a feast or a war expedition, influencing the several tribes by taking an active concern in all business of life. They are consulted alike in public and domestic affairs, bring large dowers to their husbands, and even join the war council, which they at periods aid by their deliberations" (1840:2:94).

Yet, while capable of writing specific descriptions of female behavior that implied a significant status for Māori women, Polack 
could as readily shade into negative generalizations, drawing upon a code of observation that was familiar to his British readers. This code placed Māori women's lives and their relations with Māori men within the context of a supposed scale of civilization that foregrounded the place of women in other societies, both European and non-European. In one passage Polack noted, for example, that the "forms of the young women are calculated to interest the traveler; but marriage, and the servitude with which it is accompanied in all barbarous states of society, cause early anility, and consequent decay" (1974:1:363). It was to the degraded state of women in these "barbarous" countries, he confidently told his audience, that "we"-that is, Europeans- "must attribute the unsocial habits of the people towards each other." He continued: "The example in New Zealand is not solitary; history has invariably taught us, from the deluge to our own times, that civilization has been dependent on the influence which woman has had on society; and it may be even asserted, that the absolute rise and decline of nations depend much on her conduct in social life."

The apparent paradox posed by Polack's shifting authorial position could be brushed aside as idiosyncracy were it not for the fact that this ambivalence was such a marked feature of colonial writing on Māori women generally. Granted the need, so well established most recently by Nicholas Thomas in Colonialism's Culture (1994), that we consider the historical specificities of the creation of colonial discourses, just as we should at the same time presume variability within the observed indigenous communities themselves, perhaps we should not be surprised if there are puzzling inconsistencies within such literature. But colonial texts constructing images of Māori women, with their diversity within and between texts, are strikingly diverse and confusing and have given rise to subsequent contestations surrounding the position of women from the late nineteenth century to the present. What was the basis of this anomaly?

In this chapter we contribute to a discussion of this issue through a close examination of the writings of certain European men other than missionaries who traveled through or settled in New Zealand in the period of early British colonial expansion through to the 1860 s. While the accounts written by missionaries during this period have been closely analyzed, less attention has been paid to the writings of this group. Many of these travelers and settlers lived for periods of time with Māori, spoke the language if haltingly, and sometimes established 
temporary relationships with Māori women, becoming involved with their kin. Such mobility was not an option for European women, and hence the texts created from this style of intercultural encounter were predominantly male. Women's accounts of the early period, even those by missionary wives, seldom recorded close observations of Māori for a public readership. Although there are a number of books containing the reminiscences of white women from the early colonial period, they are remarkable for their lack of information on Māori women, or Māori men for that matter. In some accounts there is simply no mention of Māori at all. Those that do mention Māori people tend to describe women only as the pupils of the settler women, learning the British forms of domestic skills. Men are described in stereotypes: as frightening warriors, nuisance beggars, or comic characters. Female travelers also often ignored the presence of Māori people or described them as amusing curiosities (see Broome 1904; Butler 1886; Stewart 1908; Wilson 1894).

Among the most prominent of these male sojourners were, apart from Polack himself, William Brown, leader of a settler group advocating direct land sales from Māori; Ernest Dieffenbach, a German naturalist who worked with the pro-settler New Zealand Company for several years; Augustus Earle and George Angas, both of them English artists; and Francis Fenton, a lawyer who served as a magistrate in the Waikato and became native secretary in 1856. All these men benefited from imperial expansion and, though they might decry certain consequences, none opposed colonization. The overall thrust of the observations of these writers and others like them ranged from those who characterized Māori as ignoble savages unable to control their immediate impulses to those who portrayed Māori as noble savages, losing their best features to corrupting European influences.

The accounts of these men and others like them are important not only because many were widely read during the colonial period-often by prospective settlers whose preconceptions of New Zealand were partly formed by such literature-but also because they have continued to be cited in anthropological and historical studies through the twentieth century. As sources for ethnohistory, they are problematic not least in terms of their geographical vagueness. Many authors indicated that they traveled extensively through New Zealand, yet few troubled to specify which areas were being referred to in the text. Herbert Meade, a naval officer who traveled from Auckland to Lake Taupo in 1864, acknowledged that Māori of different areas "differ 
much in habits and character" (1870:162), but this was most unusual. Our aim here, however, is not in this instance to enter into ethnohistorical debates on traditional Māori culture, but to address instead the meaning of these men's representations of gender.

We suggest that the signals to which British observers responded when decoding gender in Māori society were ambiguously reproduced because they at times coincided, and at other times conflicted, with the colonizers' fundamental convictions about appropriate femininity derived from their own frames of reference. Certain aspects of Māori women's behavior and appearance, and aspects of Māori men's relations with Māori women, resonated positively with male, middleclass British expectations. Yet other aspects of Māori women's lives seemed demeaning and oppressive when judged against an ideal model of the European woman. These writers negotiated a constant, sharp tension between their empirical observations of Māori women's lives and the social theory that informed their efforts to situate those observations within a comparative context.

By examining particular aspects of the accounts we have chosen, we draw out this tension in order to show how the accounts can appear so paradoxical. In each of the three areas of representation discussed below-women's position as wives and kinswomen, women as mothers, and women's physical appearance-there are both positive and negative assessments of women, often within the same text. These varying assessments are based on different and often conflicting sets of criteria, yet they are always dominated by the basic agenda: to evaluate women's overall status in accordance with contemporary European notions of ideal gender roles and relations. Before turning to the representations of Māori women, we briefly discuss these Western models, together with recent academic reassessments that have attempted to unravel the paradoxes they created.

\section{Māori and the "Woman Question"}

European intellectuals' questioning of the social status of women dated from the Enlightenment and earlier. When French socialist Charles Fourier wrote in 1808 that "the extension of the privileges of women is the fundamental cause of all social progress" (1971:131), he gave enhanced currency to the notion that gender was a significant marker of social progress, an idea that would be reiterated by eminent social theorists throughout the nineteenth century, 
Karl Marx, John Stuart Mill, and Friedrich Engels among them. For European intellectuals the fundamental criterion by which women's standing would be assessed was the degree to which male power over women was structured through legal systems and social conventions and also enforced personally through direct physical violence.

English and American evangelical Christians, from the late eighteenth century onward, substantially enlarged the discourses, constructing models of ideal gender relations as they strove to exert influence over societies fast being transformed by industrialization and urbanization. The good woman, evangelicals asserted, was the core of a decent and moral family and community. The adult married woman was ideally a good helpmeet to her husband, the conscience and the stabilizer of the man. Chaste in youth, faithful in marriage, she was also an active mother, close to her children, watchful and prudent. Women certainly had work to do, since theirs was a utilitarian, not a decorative model of femininity, but not in hard physical labor: Their important work lay in the concerns of the family and the home (Davidoff and Hall 1987; Grimshaw 1989, 1994).

An excerpt from the account of a naval officer, William Marshall, who made two visits to New Zealand in 1834, illustrates something of this integration of notions of women's social status with women's personal behavior. He talked of Māori women as "everywhere the miserable drudges of society, except where the benign influence of Christianity has brought out their emancipation from the galling yoke of abject servitude to the other sex" (1836:12). Marshall noted approvingly the labors of the Church Missionary Society among Māori communities and applauded the presence of mission wives. His comment, in fuller detail, is revealing: "Among tribes of savages, where the women are unchaste, and neither gentle nor kindly affectioned, owing to the miserable state of degradation to which they have been reduced, the presence of Christian females, as well as of Christian men, is necessary to raise the morality of those tribes, by rescuing their wives, and sisters, and daughters, from the twofold degradation of social inferiority and personal impurity" (52).

The final phrase, "the twofold degradation of social inferiority and personal impurity," captures nicely the model of womanhood that blended questions of civil status with sexual purity and self-restraint. Marshall was pro-mission, and such attitudes we might expect from evangelical missionaries and their supporters. But while the male observers of our study displayed a range of intellectual and religious ori- 
entations, most sustained similar standards to those of Marshall for evaluating the status of women, even if their personal attachment to these standards was unevenly or partially applied.

It is not surprising that European men on imperial frontiers who held such views could assess indigenous women in partially or wholly negative terms, given the culturally specific bases of their expectations. Most pertinent for comparative perspectives of Māori were the Australian colonies. Aboriginal women were among those whom settlers deemed most grievously oppressed, gazed at through this distorting mirror. Joel Polack was one of many who hastened to compare Māori favorably. In sad contrast with Australian Aborigines, Polack claimed, Māori women were "not held in the sole light as being creatures of convenience, and consequently victims to the unceasing caprice and ungovernable passions of men" (1840:2:130). The artist George Angas also stated that women held a far higher position among Māori than women in "the aboriginal tribes of Australia; by whom the sex are degraded and despised to the lowest degree- a sure mark of the inferior grade, of those people in the scale of humanity" (1967:317). Clearly, the destructive consequences of Australian settlers' reports were reverberating widely (Grimshaw and May 1994).

As part of the debate on gender and colonialism, certain postcolonial scholars have suggested a central role for European assessments of the status of indigenous women in Africa, the Middle East, and Asia (for example, see Sangari and Vaid 1990). To pursue this issue for Māori society brings us immediately to the paradox posed by Polack's unstable speaking position, a paradox further exemplified in twentieth-century ethnohistorical writing on Māori. Two scholars in particular, Caroline Ralston and F. Allan Hanson, have in recent years illustrated the contested nature of writing on Māori by their striking revisionist interpretation of the position of women as established in early anthropological work of such scholars as Elsdon Best (1924). In this early anthropological work the emphasis was on women's "polluting" nature, which was said to repel the gods and necessitate the restriction of women's activities. We mention Hanson and Ralston here not to debate their claims but to draw attention to the ways in which sources such as those we are discussing have been used in differing ways in both early- and late-twentieth-century representations.

Hanson's reinterpretation of the early literature on women in Polynesia, in his paper "Female Pollution in Oceania?" (1982), has been highly influential in Pacific studies. Hanson, with special attention to 
Māori, challenged the "repellent thesis" found in earlier work, in which Polynesian women were seen as repelling the gods due to their inherently polluting nature. He suggested that this reading should be replaced with an "affinity thesis," in which women were seen to act as conduits between the earthly and spiritual realms and therefore to attract, rather than repel, tapu. "Noa," which had been translated as "profane," should instead be seen as the absence of tapu.

In Hanson's view, both women and men could be tapu and noa according to the circumstances, and certain high chiefs and priests of either sex were always tapu. Women's association with the supernatural world was, in this revision, especially strong through their reproductive functions. The restrictions on women's activities that had been noted since the earliest accounts were reinterpreted in terms of a careful controlling of women's potency. Ralston has claimed that this revised view revealed "the misinterpretations and undervaluing of female power and participation" in earlier accounts of Polynesian women (1987:120).

Ralston's argument in her 1993 article, “Māori Women and the Politics of Tradition: What Roles and Power Did, Do and Should Māori Women Exercise?” is informed by Hanson's important paper, as is true for such Pacific scholars as Roger Keesing (1985) and Nicholas Thomas (1990), who also supported Hanson's view. Ralston read the early sources from New Zealand specifically for evidence of women's agency and power. She concludes that there is evidence of "the independent, politically active, and participatory nature of women's lives in the early contact period" (38). Indeed, Ralston implies that strongly negative accounts of Māori women only began to emerge in the 1920s, with the early ethnographic work of Elsdon Best (33). It is these later, negative accounts that she sees as underpinning the present construction of tradition, particularly by Māori males. Ralston's selection and interpretation of the early accounts needs to be understood in the context of a clear agenda, concerning "the way the denial of rights to speak on the marae is extrapolated to a denial or questioning of women's rights to any leadership role in significant contemporary political, religious, and social affairs" (26).

It is clear that the questions posed by postcolonial scholars cannot have a simple answer, as shown by the highly ambiguous nature of the accounts of Māori gender relations by the British in New Zealand. We proceed now to look at the nature of their narratives of Māori gender through a closer examination of our chosen texts. 


\section{Wives and Kinswomen: A Share of Influence or Miserable Drudges?}

In Māori Marriage, Bruce Biggs cites a Māori saying: "He puta tana ki te taane he whaanau tamariki ki te wahine" ("The battlefield for a man, the child bed for a woman") (1960:60). In the early literature on Māori, it is certainly the first that predominates: men and war. Whatever early male settlers and colonists wrote about Māori women was embedded in accounts dominated by European responses to Māori men. Visitors were overwhelmed with the force and power of the men, and in particular, their capacity as warriors, their martial skills, their bravery, their ferocity. A Marist missionary, Chouvet, who lived in New Zealand from 1843 to 1846, wrote with resignation: "After having drunk a war-like temperament with their mother's milk, they hear every day of their childhood, their fathers, their mothers and their neighbors praising the glory of arms, singing of the courage and deeds of warriors and applauding the massacre of their enemies. It is easy then to understand why men brought up this way think only of fighting" (1985:16).

Most of those outside the mission camp referred to this male bellicosity with a mixture of awe and admiration, which informed their descriptions of Māori male physique and personal appearance. The darkest side of Māori warfare, the practice of cannibalism, was spoken of with fear, but the men's courage and manly bearing in war evoked widespread praise. It was not surprising that white male invaders of Māoriland would have their main dealings with-and hence form their most powerful impressions of-Māori men. Yet their texts also make clear that Māori women were visibly present and not to be ignored.

It must be emphasized that the early chroniclers often left unclear the status of the Māori women under examination, whether chiefly or commoner. They were quite clear about one matter: They insisted that slave women, along with slave men, were treated cruelly by all other Māori, male or female. According to the early accounts the slaves undertook the hardest labor, were denied basic rights, and led miserable existences. It was suggested, however, that the condition of slavery was a temporary condition, not a permanent ascriptive status. The majority of these texts referred to women who were not slaves.

The visitors and early settlers who described Māori society pointed frequently and with surprise to the important place of Māori women 
and to the degree of influence and power they at times clearly possessed. Māori women, it seemed, were extremely significant socially, and seen so by their husbands, their children, their kin, and their tribal group. Wrote Brown: "The women are not held in bondage, but have a share of influence corresponding with the natural strength of their character" (1845:38). Dieffenbach saw Māori women treated by men "with great consideration and kindness, enjoying the full exercise of their free will, and possessing a remarkable influence in all the affairs of a tribe" (1843:11). Angas noted that Māori women often exercised "the greatest influence over their tribes; especially the widows of important chiefs, or aged women, some of whom are supposed to possess the power of witchcraft and sorcery" (1967:317).

Not apathetic or reticent spectators of any major occasion, Māori women organized resources, marshaled a labor force, and welcomed and entertained guests, visibly and volubly active participants. "On feasts being given or when a fishing party is proposed, the first wife is accounted mistress of the ceremonies, and is looked up to with deference accordingly" (Polack 1840:1:155). This pivotal role flowed from the active part women played in essential labor: in agriculture, preparing soil for planting, sowing and reaping, in cooking the food; and in weaving mats, cloaks, and baskets. Non-slave women appear to have undertaken similar work, whatever their age or standing. Many men reiterated the claim of the missionary Samuel Marsden of the Church Missionary Society that female chiefs undertook physical labor, when on a visit in 1819 he observed the wife of the chief Hongi Heke digging a potato field. He expressed appreciation that "a woman of the first rank" would labor alongside her servants and children (Elder 1932:166). Others recorded chiefly women as principally overseers of their husbands' lands, but certainly as not averse to incidental tasks of an apparently menial kind.

The strength Māori women displayed in work was portrayed as a reflection of their wider influence in their families and tribal groups. In European eyes the most remarkable demonstration of their courage-and their influence-was women's involvement on the battlefield. Wives accompanied husbands to battle, spurring them on to deeds of valor, singing, shouting, and supporting their men in every way. Sometimes, indeed, they entered the fray themselves. The naval officer John Nicholas noted one chiefly wife who displayed "the most undaunted spirit, rivaling the boldest men in deeds of heroism, and selecting for her antagonist the most formidable she could find." Such 
warrior women were, he hastened to add, only "certain ladies of more intrepid character than the rest" (1817:1:199).

Earle, like so many writers, recorded the loyalty and devotion of women to their husbands. He described elderly couples who had married in youth, lived happily together all their lives, and "whose kind and friendly manner towards each other set an example well worthy of imitation in many English families" (1966:180). Whereas Dieffenbach described wives as their husbands' "constant companions" (1843:39), Brown thought that married couples could sustain a disconcerting distance from each other, as though unrelated, and could be found sleeping separately quite soon after marriage. But it was rare, noted Brown, for married couples to quarrel and "still rarer for a husband to beat his wife" (1845:33).

The depth of wives' attachment to husbands was said to be measured by their supreme bravery, when husbands died or were killed in warfare, in committing suicide, mostly by hanging or drowning themselves. The early observers claimed that the wives themselves took courageous initiative, apparently driven by their overwhelming grief and desperate wish to follow their husbands to the grave: No prompting or persuasion was needed. Stories were told of dramatic, public acts of suicide at the news of a husband's sudden death and of agonized wives plaiting their suicide ropes as they kept watch at their husbands' deathbeds. "The ardour of affection or rather devotion, that has been exhibited by the sex in New Zealand, has never been surpassed in any period or in any country," thought Polack (1840: $1: 156)$.

Writers of these same accounts detailing the influence and status enjoyed by many Māori women frequently made starkly contradictory statements about women's status when moved to offer generalizations. Many commented, after all this description, on women's “degraded state." Nicholas, while claiming that single women were equal to men in privileges and freedom, added that "when married, their freedom is at an end; they become mere slaves, and sink gradually into domestic drudges to those who have the power of life and death over them" (1817:1:180). He used this as an occasion to philosophize-as early as 1817 -about the way in which women were treated more kindly the more civilized a nation was $(2: 301)$.

Within the early settlers' and visitors' texts, then, were observations of discordant elements in women's roles as wives and kinswomen that writers sometimes tried to synthesize with these positive observations, 
at other times not. Polack himself pointed to the dramatic feature of marriage that mesmerized this group of observers: that the errant wife risked instant death at the hands of her vengeful husband when she was found in an adulterous relationship. Māori women were praised for holding fidelity in marriage in high esteem, but the sanctions for transgression were certainly awful. "The favours of a married woman in New Zealand are fully as difficult of attainment as in any part of the world, the punishment of death being awarded as the penalty for an infringement of the nuptial bond, which is held by these people in as sacred a light as in the most civilised states" (1974: 1:369). The traveler Samuel Martin claimed that marriage was "regarded as a most solemn ordinance" in which "married women enjoy as much liberty and exercise as much influence as they do in Europe" (1845:304). But, he noted, "crimes on their part are visited with the sternness and cruelty of Eastern despotism. Infidelity is invariably visited with death."

And so although casual domestic violence was rarely reported, writers emphasized that husbands sustained this overwhelmingly terrible right to kill outright an adulterous wife. There was no real reciprocity in sexual restraint, since polygamy was said to prevail. There was a great deal of confusion about the extent of polygamy. Some authors said it only occurred among chiefs, and yet others denied that it was common at all. Most claimed that men had legitimate sexual access to several women or wives. The reasons for polygamy seemed on the face of it to prioritize a man's sexual interests while sustaining women's fidelity through draconian penalties.

As to the origins of polygamy, Nicholas declared himself in favor of an economic explanation. The first wife was acknowledged as superior, subsequent wives inferior: "I am disposed to think that the chiefs take them rather for their manual services, than for the charms of their persons or the endearments of their society. Indeed they may be considered in no other light than as hard-working servants, having no honor assigned to them but that of distinguished drudgery" (Nicholas 1817:1:293). Not a few other observers similarly reported chiefs claiming that without wives' work in overseeing and working in gardens, they could not sustain their agricultural enterprises at all.

But polygamy was also seen as the cause of many evils, largely arising from the jealousy of co-wives. Polack claimed that polygamy was "greatly abhorred by the females of the country" and that it caused "unhappiness and incessant brawling" (1840:1:147). Even if this was 
not always so, these writers asked, did not polygamy of itself imply a low status for women, whatever the justifications? Observers occasionally noted that if men had the power of life and death over wives in these circumstances, they might well suffer retribution at the hands of their wives' relatives. Overall, however, the emphasis was on tales of swift, brutal, barbaric murder.

\section{Women as Mothers, Women as Murderers?}

In contrast to the Māori proverb claiming "the child bed for a woman," European recorders placed Māori women most centrally as wives rather than mothers. Once again, however, when these observers did turn their attention to motherhood, they could write affirmatively of Māori women's maternal capacities. The women, it was said, greatly desired children. Indeed Francis Fenton believed that a woman was "usually held in respect according to the number of children with which she had strengthened the tribe" (1859:27). Childless wives were inconsolable, he said, and engaged in ceremonies to intercede with the gods to aid conception (30). Women's health and strength were emphasized in descriptions of the ease with which they experienced childbirth. Nicholas reported that women sat in the open air, surrounded by men and women, and gave birth "without uttering a single groan." Thereupon the new mother cut the umbilical cord herself, and "rose up as if no such occurrence had taken place, and resumed her ordinary occupations" (1817:2:171; see also Dieffenbach 1843:24; Polack 1974:2:272). Babies were "nursed with affection and tenderness" (Dieffenbach 1843:26), and breast-feeding was said to extend as long as to the third year. Mothers showed their young a fierce loyalty, and children traced their all-important descent lines through mothers' as well as fathers' lineages. The children were introduced very early into the meaning of their place in a family. When a much-loved husband was killed in battle, a chiefly wife voluntarily resigned not only herself but her children to the victors, "to kill if they wished, as they had done to her husband" (Elder 1932:174). Within the collectivity of the marriage, the family, or the kin group, mothers fostered their children as precious and similarly loyal young people. There was no suggestion, as in some other parts of the Pacific, that mothers were "unnatural" and unable to care for their children “properly" (see Jolly 1991; Grimshaw 1989).

But motherhood, like wifehood, had its terrible aspect; and the two 
were linked. At the feet of polygamy was laid the cause for a terrible act perpetrated by mothers: infanticide. Jealous wives were said to kill their infants to spite husbands who took new wives or offended them in any way. Brown wrote that "should a husband quarrel with his wife, she would not hesitate to kill her children merely to annoy him" (1845:41; emphasis in original).

In this case the wife's act was seen as one of defiance, implying power, not as an indication of servility or degradation. Indeed, one reason given for the surprising observation that fathers, even great chiefs, could be seen carrying infants around on their backs for much of the day, nestled into their cloaks, was the fear that the child was in jeopardy from a revengeful mother (Polack 1840:2:93). For others, the Māori fathers' care of infants and toddlers was in part touching and impressive, in part puzzling indeed. Why did grown men devote so much time to the very young? The Europeans knew of "wet nurses," but they dubbed these fathers "dry nurses" (Polack 1974:2: 273). What did this imply for the notion of Māori motherhood? Truly, both parents seemed amazingly indulgent of young children, scarcely ever correcting them and leading them with great kindness into the knowledge and skills they would need in adult life. The Europeans contemplated the "cheeky" questions and "pestering" behavior of children askance, but could certainly say that if babies survived their births, they could look forward to careful and loving nurture.

Infanticide, however, was by far the most widely discussed feature of Māori motherhood. Despite the fact that it was rare for observers to go so far as to claim that they had actually seen the act of infanticide, all claimed that it was common and confessed to by countless informants. William Yate, who served with the Church Missionary Society in the Bay of Islands, was one of the few to claim that he witnessed several cases of infanticide, which he, too, blamed on women's jealousy of co-wives (1970:98). Other reasons for infanticide were canvassed, although these were similarly related to the issue of women's status. Was infanticide weighted toward infant girls? Many observers asserted this to be the case. Marshall thought so: "The murder of the female infant after birth, is however often perpetrated by its own mother under a smarting sense of the indignities and sufferings to which every female is exposed, long before she arrives at womanhood, and generally to the latest hour of her life.... The fortitude of women, proof against everything but man's neglect, may be overcome, until even natural affection cease to animate her, and the 
love of the mother be absorbed in the misery of the woman. A greater proof of the degraded estate of the female sex in New Zealand cannot exist, than that which their very crimes, stated above, supply" (Marshall 1836:14).

Brown wrote that males being much more esteemed than females, "the latter are chiefly the victims, and are sacrificed that they may escape future miseries" (1845:41; see also Polack 1840:2:94). Earle elaborated on this, claiming the women's excuse given for killing baby girls was "that they were quite as much trouble to rear, and consumed just as much food, as a male child, and yet, when grown up, they were not fit to go to war as their boys were" (1966:179). Again, Fenton reported that mothers killed daughters in order to flee enemies unencumbered, but spared baby sons since they would in time be warriors (1859:30).

Yet some Europeans denied that infanticide was prevalent, and others, such as Dieffenbach (1843:26), denied a distinction made by sex. Despite these conflicting reports, and whatever the truth of the matter, the existence of so many graphic and emotive accounts of infanticide meant that assessments of Māori women as wives and mothers were inevitably influenced negatively, affecting popular perceptions of Māori women.

\section{(Promiscuous) Young Beauties and (Chaste) Old Hags}

When Dieffenbach described Māori women as well treated, autonomous, and influential in tribal affairs as mentioned previously, he qualified his remarks with a description of the adverse physical consequences of their arduous work. Apart from the daughters of high chiefs, Māori women, he stressed, "are burdened with all the heavy work; they have to cultivate the fields, to carry from their distant plantations wood and provisions, and to bear heavy loads during their traveling excursions" (1843:12). He added that "early intercourse," "frequent abortions," and their prolonged suckling of children contributed "to cause the early decay of their youth and beauty and [were] prejudicial to the full development of their frame." Most writers also found abhorrent the mature women's moko, or tattooing on the chin.

Observers were unanimous that Māori women, occasional highborn women excepted, aged rapidly. Brown stated that "women arrive very early at maturity, and as early become old and withered" (1845: 
38). As did many other observers, he claimed that girls married very early, and had lost their youth by the age of thirty (Angas 1967:311; Polack 1840:2:175). For some this rapid aging was blamed on their early "promiscuity," and other women were said to be worn down prematurely through the physical toll exacted by their bountiful giving and nurturing of the lives of children, kin, and tribal group. Amazons, mature women were often called, even if at times there could be "a good-looking, self-willed sort of Amazon," as when a woman saved a group of Europeans from death (Meade 1870:133). Meade reported that when his party was captured by Kingites and facing death, a Māori woman used her influence to help save them. He described her as "possessing no little influence, a well-made, rather good-looking person, but strong-minded and imperious" (87).

If the women's labor was worthy, was it nice? Was it becoming? Nicholas observed women participating as equals with men in a canoe race and joining the vociferous singing at the race's end; he found their exertions violent, inappropriate: "The distinction of sex appearing no longer visible, was completely lost in their convulsive excesses" (1817:1:363-364). Māori women may have often seemed to have some freedom of action in public domains; but even if this revealed power, did it go beyond acceptable limits for their sex? And could these public engagements all be justified if the end result was bodies marked by time, bodies that were masculinized?

This concern with women's rapid aging and their "masculine" appearance and behavior reflects the preoccupation of many of the male writers with women's sexuality. Women's appearance is discussed as a measure of their sexual attractiveness to the white male observers. This and other aspects of their sexuality, such as their chastity (or lack thereof) and the extent of women's control over their own bodies in sexual relations and in reproduction were often the predominant foci of accounts of Māori women.

The men who settled in and traveled through New Zealand, many of whom were only in their early twenties, were particularly interested in young chiefly women. Dieffenbach's description of such women's appearance as "handsome and attractive ... heightened by a natural modesty and childlike naivete" (1843:12) echoed the many similar comments. The attractive Māori women who caught the male eye were young-often very young indeed. Many observers likened these women to beautiful gypsies (for example, Angas 1967:310; Dilke 1869:256), or, as in Polack's description of a young girl he saw in the 
Kaipara district, to Spanish women: "She was distinguished from the females of the village by her demeanor, which was dignified and graceful; her countenance was eminently beautiful, which was worthy, as to complexion and feature, of being put in competition with the beauteous women of Spain. Her delicacy of appearance was most prepossessing; and I imagined her disposition equally pleasing, from a succession of smiles hovering round her mouth, displaying teeth of unrivalled evenness and whiteness. Her charms were much enhanced by the modest and artless simplicity which evidently composed her usual manners" (1974:1:124).

Edward Markham, an educated and wealthy traveler, espied many such pretty young women when he was in Hokianga and the Bay of Islands in 1834. He wrote: "I have seen some very fine creatures and even beautiful. The breasts are uncovered in warm weather, and an unmarried woman takes it as a compliment for you to put your hands on them" (1963:40). He found it useful to attach himself to one such chiefly woman for protection "as they are always backed by their Tribe and you are not robbed or molested in that case; they become useful and very much attached if used well, and will suffer incredible persecution for the men they live with.” The Māori tried to marry off the girls at a young age, he claimed, because they would not "keep" (69).

Individual young girls with their fine figures, long flowing hair, laughing eyes, and delicate hands and feet were portrayed as lovely indeed, charming potential sexual partners and protectors of European men's homes. But there was a problem here too, of course, when their availability was assessed within a context of women's status. Young women were apparently not chaste, not chaste at all, according to these accounts. They were said to have a series of sexual encounters with Māori youth. Wrote Earle: "While they remain single they enjoy all the privileges of the other sex; they may rove where they please, and bestow their favours on whom they choose, and are entirely beyond control or restraint" (1966:180). Those living near ports exchanged sexual favours for European goods with apparent alacrity, although there was considerable disagreement among observers as to the extent of women's willing participation and whether or not they were "naturally licentious." Many said that at first these were slave women (Ollivier 1986:99); others declared any unmarried women except chiefly women were participating. Was this not sheer prostitution? And were not prostitutes of low status? But the women 
who were chaste, their mothers and grandmothers, were viewed as singularly unattractive, unfeminine in appearance and demeanor.

\section{Conclusion}

In 1888 a colonist named Thomas Moser published a selection of sketches of New Zealand life, entitled Mahoe Leaves, that he claimed offered "a faithful delineation of Māori life and character" (Preface). He himself was, he pointed out, "a trifle higher in the social scale than a Māori” (83). The tract contains appalling racist sentiment. Note, for example, this description of an elderly Māori woman: "Look at her features, smoke-dried and shrivelled; her back half bent double; her wretched hands and feet attenuated and shrunk till they look more like the claws of some horrid bird than a human being. ... Some Mummies that I have seen are Venuses compared with her!" (28) Such grotesque characterizations of Māori women in the latenineteenth-century settler literature are not infrequent and certainly wounding.

Yet a fuller consideration of gender within colonial discourse in New Zealand suggests far greater ambiguities than feminist postcolonial scholars have suggested for other times and places. There is no doubt that decided strengths of Māori women's position were widely canvassed. As Charles Wentworth Dilke wrote in his account of his travels (he had been to America, India, Australia, Ceylon), published in the late 1860s: "The delicacy of treatment shown by the Māoris toward their women may go far to account for the absence of contempt for the native race among the English population" (1869:270). Compare the drudgery, he suggested, to which American Indian women or Indian women were subjected: "It is the New Zealand native's treatment of his wife that makes it possible for an honest Englishman, to respect or love an honest Māori.”

Here was a positive view of colonial attitudes to Māori. But others were not convinced that the settlers pouring into the country saw things the same way. Edward Shortland was one who, employed as "Protector of the Aborigines," strove to defend their reputation. In January 1850 a writer in the Edinburgh Review claimed that some years before, a chief's wife was hung naked by the heels before the whole tribe and beaten, and that she subsequently committed suicide. Brown, for one, had related this story in his account of New Zealand published in 1845 . Now, in the early 1850 s, it surfaced again. Short- 
land declared in turn that he personally knew the story to be false: This was "a mode of punishing a female which I have never heard of as having ever occurred in New Zealand" (1974:64). The story was fabricated for one reason only, he said, to persuade European settlers to think unfavorably of Màori. He pointed at the same time to the description of Māori women's onerous work. Māori men, not women, performed the largest proportion of heavy work; some privileged Māori women, by contrast, were principally engaged in domestic pursuits suitable to their sex. If other Māori women did perform heavy labor, he reminded his readers, this was true of many British women also.

With such defenders, Māori women would not emerge in this colonial discourse as totally oppressed victims. Yet in so many cases the early colonial writers raised affirmative descriptions of Māori gender only to discount them swiftly with alternative indications of status. It was these denigratory characterizations that settlers could emphasize as they systematically dispossessed Māori of lands and livelihoods. Yet the same ambiguous signals in the texts have opened the avenue to a far more positive evaluation of Māori women's status emerging in modern scholarship. 